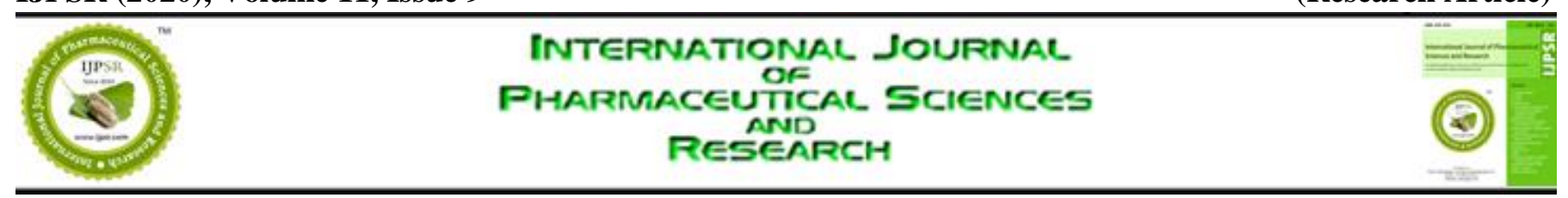

Received on 16 September 2019; received in revised form, 06 March 2020; accepted, 21 April 2020; published 01 September 2020

\title{
EFFECTS OF ALLIUM SATIVUM ON BODY WEIGHT AND BIOCHEMICAL PARAMETERS IN HEALTHY RATS
}

Sanjay Bhatt ${ }^{1}$, Kiran Malik ${ }^{2}$ and Vishnu Kumar ${ }^{* 1}$

Department of Biochemistry ${ }^{1}$, Shri Ram Murti Smarak Institute of Medical Sciences, Bareilly - 243202, Uttar Pradesh, India.

Department of Biochemistry ${ }^{2}$, Autonomous State Medical College, Dharnipur, Jignera, Shahjahanpur 242001, Uttar Pradesh, India.

Keywords:

Allium sativum, Hepatospecific parameters, Post heparin lipolytic activity, Plant antioxidant

\section{Correspondence to Author:}

Dr. Vishnu Kumar

Professor,

Department of Biochemistry,

Shri Ram Murti Smarak Institute of

Medical Sciences, Bareilly - 243202,

Uttar Pradesh, India.

E-mail: madhwapur1976@gmail.com

\begin{abstract}
This case-control study had undertaken to evaluate effect of Allium sativum in normal rats. In this study ethanol extract of Allium sativum had macerated with aqueous gum acacia $(2 \%, w / v)$ suspension and fed orally $(500 \mathrm{mg} / \mathrm{kg} \mathrm{b} \mathrm{w} \mathrm{p.} \mathrm{o.)} \mathrm{to} \mathrm{male} \mathrm{adult} \mathrm{normal} \mathrm{rats} \mathrm{of} \mathrm{charles} \mathrm{foster} \mathrm{strain} \mathrm{for} 15$ days. Results of this study showing that alcoholic extracts caused no any significant reduction in blood glucose, total cholesterol, triglyceride, phospholipids, free fatty acid, lipid peroxide and no significant increased in post heparin lipolytic activity, but on the other hand as per pre-existing data and my published studies in diabetic patients and diabetic experimental animals showed that extracts exert all above effects significantly. That's why it is very clear here if a healthy person will take natural products, it never causes hypoglycemia, hypolipidemia, and under the weight. Natural products also not cause any significant change in hepatospecific parameters. Thus, from this study, we conclude that natural products are safe, non-toxic, and free from side effects, in comparison to synthetic drugs.
\end{abstract}

INTRODUCTION: Allium sativum (Lat.), (Eng: Garlic, Urdu: 'Lahsan') is widely distributed in all parts of the world and used not only as a spice but also as a popular remedy for prevention and treatment of a variety of diseases like rheumatism, dermatitis, abdominal disorders, and diabetes mellitus. Effect of garlic in cardiovascular diseases was more encouraging in experimental studies, which prompted several clinical trials. Dietary factors play a key role in the development of various human diseases, including cardiovascular disease.

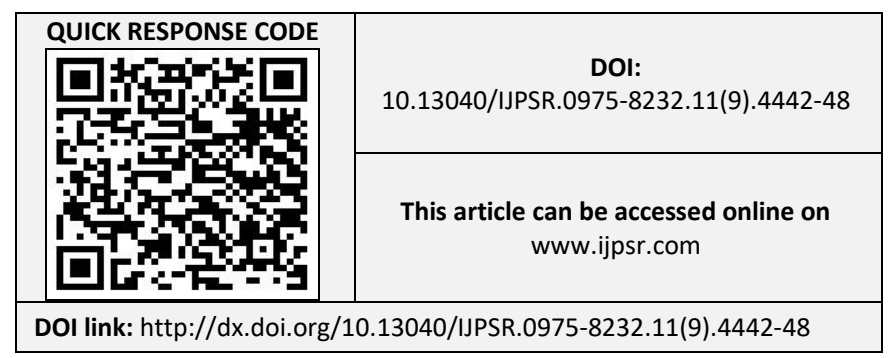

Garlic has attracted particular attention of modern medicine because of its widespread health use around the world and the cherished belief that it helps in maintaining good health warding off illnesses and providing more vigor. To date, many favorable experimental and clinical effects of garlic preparations, including garlic extract, have been reported. These biological responses have been largely attributed to reduction of risk factors for cardiovascular diseases, cancer and stimulation of immune functions, enhanced detoxification of foreign compound, hepatoprotective, antimicrobial effect and antioxidant effect ${ }^{1}$.

Garlic is reported to prevent cardiovascular disease by multiple effects, one of which is the decrease total cholesterol and triglycerides ${ }^{2}$, LDLC, VLDLC, while increase HDLC ${ }^{3}$ and suppression of the cholesterol biosynthesis ${ }^{4}$. Studies prior to 1995 consistently concluded hypolipidemic action 
of garlic 5, 6 . However, studies after 1995 using enteric-coated preparation of raw garlic did not manifest any hypolipidemic effect 7,9 . These paradoxical observations warrant a systemic study to resolve the controversy.

It is a remarkable plant, which has multiple beneficial effects such as antimicrobial, antithrombotic, hypolipidemic, antiarthritic, hypoglycemic and antitumor activity. Additionally, garlic has known hypoglycemic properties, which have been demonstrated in alloxan induced diabetic rats and rabbits. The extract of garlic and its component, S-allylcysteine sulfoxide, significantly decreased blood glucose concentration. Its activity appears to be in part due to the stimulation of insulin secretion from $\beta$-cell in the pancreas ${ }^{10}$.

Cardiovascular diseases are leading cause of death in both industrialized and developing nations ${ }^{11}$. Disorders of lipid metabolism following oxidative stress are the prime risk factors for the initiation and progression of heart diseases ${ }^{12}$. The current therapies used for controlling hyperlipidemia, fibrates, stains, and bile acid sequestrations are almost inefficient to regulate lipid metabolism. Furthermore, these drugs also cause a number of serious adverse effects in patients. Currently available treatment for hyperlipidemia in modern medicine, fibrates, statins, or bile acids sequestrants and their combinations do not regulate lipid metabolism up to an appreciable mark, also have several adverse effects in patients ${ }^{13}$. Therefore, there is a need to develop safe and effective treatment modalities for hyperlipidemia. Furthermore, medicinal plants play an important role in the treatment of lipid disorders, especially due to their lesser toxicity, side effects, and cost-effectiveness. Therefore, the research and development of hypoglycemic and lipid-lowering drugs from natural products are the best option and also are in great demand. In view of the above considerations, the present study was designed to investigate the adverse effects of $A$. sativum in normal rats.

\section{MATERIALS AND METHODS:}

Preparation of Allium sativum Extract: Allium sativum were collected from the local area of Lucknow and identified taxonomically by the Department of Pharmacology, Era's Lucknow Medical College Lucknow.
A voucher specimen (AS-005/10) was also submitted. The bulbs of garlic (A. sativum) were cut into small pieces and extracted with alcohol. The alcohol content was evaporated to dryness. The final yield of 20.0 gms of crude extract (concentrate) was added with $50 \mathrm{ml}$ of triple distilled water and was used for in-vivo studies. A dose of $400 \mathrm{mg} / \mathrm{Kg}$ was administered to rats orally, daily for 15 days ${ }^{14}$.

Animals: In-vivo experiments were conducted as per guidelines provided by the Animal Ethics Committee of Central Drug Research Institute, Lucknow, India. Male adult rats of Charles Foster strain (200-225 g) bred in the animal house of the Institute were used. The animals were housed in polypropylene cages and kept in uniform hygienic conditions, temperature $25-26{ }^{\circ} \mathrm{C}$, relative humidity $50-60 \%$, and $12 / 12 \mathrm{~h} \mathrm{light/dark}$ cycle (light from 8:00 an $\mathrm{m}$ to $8: 00 \mathrm{pm}$ ) and provided with standard rat pellet diet and water ad libitum.

Preparation of Doses: A quantity of $50 \mathrm{mg}$ Allium sativum extract was suspended $/ \mathrm{ml}$ tripled distilled water (TDW) containing $2 \%(\mathrm{w} / \mathrm{v})$ gum acacia. The suspension was given in a volume of $1 \mathrm{ml} / 100 \mathrm{~g}$ animal b. w. (500 mg drug / $\mathrm{kg} \mathrm{b.} \mathrm{w.)} \mathrm{by} \mathrm{oral}$ intubation.

Chemicals: Blood glucose (BLG), Total cholesterol (TC), triglycerides (TG), Phospholipid (PL) were analyzed using standard kits from Erba Diagnostic (Mannheim Gmb H, Germany) by an auto-analyzer (Erba Mannheim, EM 360, Germany). Intralipid from victrum $\mathrm{AB}$, In the Kabivitrum Group, Stockholm, Sweden ${ }^{15}$.

Experimental Animals: Healthy male adult rats of Charles Foster strain (200-250 g) bred in the animal house of the Central Drug Research Institute, Lucknow, were used. The animals were kept in controlled conditions; temperature 25-26 ${ }^{\circ} \mathrm{C}$, relative humidity $60-70 \%$, and 12/12 h light / dark cycle (Light from 08:00 AM to 08:00 PM), provided with standard pellet diet (Lipton India Ltd.) and water ad libitum ${ }^{15}$.

Experimental Design: The rats were divided in five groups having six animals in each as follows: group 1; normal control rats (on normal saline); group 2; Allium sativum treated normal rats ${ }^{15}$. 
Assessment of Biochemical Parameters: The blood was centrifuged, and plasma was separated. The fasting blood sugar (FBS) was analyzed in plasma; superoxide dismutase (SOD), catalase (CAT), hepatic triglyceride lipase (TGL), and lipoprotein lipase (LPL) were estimated in liver homogenate.

Serum total cholesterol (TC), triglyceride (TG), high-density lipoprotein total cholesterol (HDLTC), serum bilirubin, SGPT, SGOT, and alkaline phosphatase were assayed by standard spectrophotometric kit methods. Low-density lipoprotein total cholesterol (LDL-TC) and very-low-density lipoprotein total cholesterol (VLDL-TC) were calculated by Friedewald's equation. Serum was also used for the assay of lecithin cholesterol acyltransferase activity (LCAT), lipid peroxide (LPO), and reduced glutathione (GSH).

A portion of serum was fractionated into very-lowdensity lipoprotein (VLDL), low-density lipoprotein (LDL), and high-density lipoprotein (HDL) by polyanionic precipitation methods. Lipoproteins were measured for their total cholesterol (TC), phospholipids (PL), triglyceride (TG), and apo- protein by standard spectrophotometric methods in the liver homogenate ${ }^{15-30}$.

Statistical Analysis: One-way analysis of variance (ANOVA-Newman's Student t-test) was performed by comparison of values for a normal treated group with normal healthy control. All hypothesis testing was two-tailed. $\mathrm{P}<0.05$ was considered statistically significant, and the results were expressed as Mean \pm SD. The graph pad in State 3.0 software was used to carry out the statistical analysis ${ }^{31}$.

RESULTS: Effect of drug treatment on body weight of drug-treated normal rats after 1 month with respect to normal control without drug-treated. Weight of all experimental rats (Normal control without drug-treated and drug-treated) was recorded in the beginning of the study and after completion of the study. Percent change in weight of rats after 15 days, at the end of the study, as compared with respect to the value of the weight of rats on study day 0 (Beginning). No significant change in weight of drug-treated normal rats was found with respect to normal control without drugtreated, after 15 days, in the end of the study, Table 1.

\begin{tabular}{|c|c|c|c|c|}
\hline Group & \multicolumn{2}{|c|}{ Body Weight (gm) } & \multirow{2}{*}{$\begin{array}{l}\text { Percent change with respect } \\
\text { to the value of weight of rats } \\
\text { on study day } 0 \text { (Beginning) }\end{array}$} & 'p' value \\
\hline $\begin{array}{l}\text { Normal control }+2 \% \\
\text { aqueous gum acasia }\end{array}$ & $\begin{array}{l}\text { Study day 0 } \\
\text { (Beginning) }\end{array}$ & $247.50 \pm 33.90$ & & - \\
\hline & $\begin{array}{l}\text { study day } 15 \\
\text { (end of study) }\end{array}$ & $315 \pm 23.56$ & +22 & NS \\
\hline Normal control + & Study day 0 & $258.16 \pm 18.32$ & - & NS \\
\hline $\begin{array}{l}\text { Allium sativum treated } \\
\text { ( } 500 \mathrm{mg} / \mathrm{kg} \text { body weight) }\end{array}$ & Study day 15 & $329 \pm 20.70$ & 22 & NS \\
\hline
\end{tabular}

Values expressed as gram (gm) are mean \pm SD of six rats, drug-treated groups were compared with normal control. Percent change with respect to the value of the weight of rats on study day 0 (beginning). NS = Not significant

Effect of Allium sativum on Blood Glucose, Serum Lipid, and Lipoprotein Profile in Healthy Control Rats: In normal rats, administration of Allium sativum at the dose of $500 \mathrm{mg} / \mathrm{kg} \mathrm{b}$. w. orally once daily for 15 days lowered the levels of blood glucose ( $2 \%)$, TC (2\%), PL (2\%), TG (1\%), and increase in total serum protein (1\%) Table 2. Furthermore, treatment with natural test products, the lipid, and protein components of serum lipoproteins remains almost the same as that of control Table 2.

TABLE 2: EFFECTS OF ALLIUM SATIVUM ON BLOOD GLUCOSE AND SERUM LIPIDS IN NORMAL RATS

\begin{tabular}{cccccc}
\hline Experimental schedule & Blood glucose (mg/dl) & TC (mg/dl) & PL (mg/dl) & TG (mg/dl) & Protein (g/dl) \\
\hline Normal control & $89.76 \pm 10.30$ & $87.50 \pm 11.16$ & $75.96 \pm 7.36$ & $82.21 \pm 5.80$ \\
Allium sativum Treated & $88.20 \pm 1060(-2 \%)$ & $85.65 \pm 11.69(-2 \%)$ & $74.62 \pm 7.53(-2 \%)$ & $81.61 \pm 5.76(-1 \%)$ & $7.09 \pm 0.53$ \\
(500 mg/kg body weight) & & & & $(+1 \%)$ \\
\hline
\end{tabular}

Values expressed are mean \pm SD of six rats. Values with parenthesis are percentage change drug-treated groups are compared with control (Change is non-significant 
It was seen that Allium sativum caused a decrease in the level of \pm lipoprotein TC (3-5\%), PL (4-8\%), TG $(0.82-3.0 \%)$, and apolipoproteins $(0.3-1.5 \%)$ respectively.
However, herbal preparation increases lipid and protein contents of \pm lipoprotein HDL by $(0.3-7 \%)$ in Table 3.

TABLE 3: EFFECT OF ALLIUM SATIVUM ON LIPOPROTEIN PROFILE IN NORMAL RATS

\begin{tabular}{|c|c|c|c|c|c|c|c|c|c|c|c|c|}
\hline \multirow{2}{*}{$\begin{array}{l}\text { Experimental } \\
\text { schedule }\end{array}$} & \multicolumn{4}{|c|}{ Very low-density lipoprotein (VLDL) } & \multicolumn{4}{|c|}{ Low-density lipoprotein (LDL) } & \multicolumn{4}{|c|}{ High-density lipoprotein (HDL) } \\
\hline & TC & PL & TG & $\begin{array}{c}\text { Apo- } \\
\text { protein }\end{array}$ & TC & PL & TG & $\begin{array}{c}\text { Apo- } \\
\text { protein }\end{array}$ & TC & PL & TG & $\begin{array}{c}\text { Apo- } \\
\text { protein }\end{array}$ \\
\hline Norn & 8.10 & 16.80 & 40.10 & 7.00 & 17.90 & 11.98 & 20.61 & 16.87 & 51.64 & 41.18 & 14.90 & 173.80 \\
\hline & \pm 0.66 & \pm 2.06 & \pm 3.29 & \pm 0.99 & \pm 1.73 & \pm 1.43 & \pm 1.76 & \pm 2 . & \pm 5.59 & \pm 3.36 & \pm 1.51 & \pm 11.63 \\
\hline Allium & 7.70 & 16.06 & 39.77 & 7.01 & 17.40 & 11.07 & 19.90 & 16.92 & 54.78 & 41.95 & 15.07 & 174.08 \\
\hline treated $(500 \mathrm{mg} / \mathrm{kg}$ & \pm 0.54 & \pm 2.12 & \pm 3.43 & \pm 0.73 & \pm 1.66 & \pm 1.25 & \pm 1.42 & \pm 2.42 & \pm 8.27 & \pm 3.32 & \pm 1.49 & \pm 11.59 \\
\hline body weight) & $(-4.9 \%)$ & $(-3.8 \%)$ & $(1.00 \%)$ & $(-0.20 \%)$ & $(-3 \%)$ & $(-8 \%)$ & $(-3 \%)$ & $(+0.6 \%)$ & $(+6 \%)$ & $(+2 \%)$ & $(+1 \%)$ & $(+0.14 \%)$ \\
\hline
\end{tabular}

Values expressed are mean \pm SD of six rats. Values with parenthesis are percentage change. Drug treated groups are compared with control (Changes were no significant)

Effects of Allium sativum on Serum Free Fatty Acids, Hepatic Triglyceride Lipase and Total Hepatic Lipoprotein Lipase Activity Status in Normal Rats: In normal rats administration of
Allium sativum for 15 days lowered the levels of free fatty acid (1\%) hepatic triglyceride lipase (4\%) and total hepatic lipoprotein lipase activity (4\%) respectively Table 4.

TABLE 4: EFFECT OF ALLIUM SATIVUM ON SERUM FREE FATTY ACID TOTAL HEPATIC LIPOPROTEIN LIPASE AND HEPATIC TRIGLYCERIDE LIPASE ACTIVITY IN NORMAL RATS

\begin{tabular}{cccc}
\hline $\begin{array}{c}\text { Experimental } \\
\text { schedule }\end{array}$ & $\begin{array}{c}\text { Serum-free } \\
\text { fatty acid }^{\mathbf{a}}\end{array}$ & $\begin{array}{c}\text { Hepatic lipoprotein } \\
\text { lipase activity }^{\mathbf{b}}\end{array}$ & $\begin{array}{c}\text { Total hepatic lipoprotein } \\
\text { lipase activity }^{\mathbf{b}}\end{array}$ \\
\hline Normal control & $1.69 \pm 0.20$ & $71.78 \pm 7.60$ & $85.01 \pm 0.06$ \\
Allium sativum treated $(500 \mathrm{mg} / \mathrm{kg}$ body weight) & $1.65 \pm 0.12(-1.0 \%)$ & $74.65 \pm 7.48(+4 \%)$ & $88.53 \pm 4.58(+4.0 \%)$ \\
\hline
\end{tabular}

Values are expressed as mean \pm SD of six rats drug-treated groups are compared with control. (The changes are non significant); $\mathrm{a}=\mu \mathrm{mol}$ FFA/L, $\mathrm{b}=\mu$ mol FFA released $\mathrm{h} / \mathrm{mg}$ protein

Effect of Allium sativum on Serum Lipid Peroxide, Hepatic Sod and Hepatic Catalase Activity in Normal Rats: In normal rats administration of $A$. indicus, Hibiscus rosasinensis
C. tora and T. cordifolia for 15 days lowered the level of serum lipid peroxide (8\%) and increase in the levels of hepatic SOD (4\%), catalase (1.4\%) respectively Table 5.

TABLE 5: EFFECT OF ALLIUM SATIVUM ON SERUM MDA AND HEPATIC SOD, HEPATIC CATALASE ACTIVITY IN NORMAL RATS

\begin{tabular}{cccc}
\hline Experimental schedule & Serum lipid peroxide $^{\mathbf{a}}$ & Hepatic SOD $^{\mathbf{b}}$ & Hepatic CAT $^{\mathbf{b}}$ \\
\hline Normal control & $2.90 \pm 0.40$ & $2.78 \pm 0.20$ & $3853 \pm 251.40$ \\
Allium sativum treated & $2.67 \pm 0.40(-7.8 .0 \%)$ & $2.88 \pm 0.20(+4.00 \%)$ & $3910 \pm 267.08(+1.46 \%)$ \\
$(500 \mathrm{mg} / \mathrm{kg}$ body weight $)$ & & & \\
\hline
\end{tabular}

Values are expressed as mean \pm SD of six rats. Drug treated groups are compared with control. (The changes are nonsignificant); $\mathrm{a}=\mu \mathrm{mol} \mathrm{MDA} / \mathrm{ml}, \mathrm{b}=$ units $/ \mathrm{min} / \mathrm{mg}$ protein

Effect of Allium sativum on Hepatospecific Marker in Normal Control Rats: In normal rats administration of above mentioned herbal preparations for 15 days lowered the levels of
Bilirubin, SGPT, SGOT, ALP in serum by (4.83\%), $(6.99 \%),(0.99 \%)$ and $(1.64 \%)$ respectively Table 6.

TABLE 6: EFFECT OF ALLIUM SATIVUM ON THE HEPATO SPECIFIC MARKERS IN THE SERUM OF NORMAL RATS

\begin{tabular}{ccccc}
\hline & Serum bilirubin $^{\mathbf{a}}$ & SGPT $^{\mathbf{b}}$ & SGOT $^{\mathbf{b}}$ & ALP $^{\mathbf{c}}$ \\
\hline Normal control & $0.60 \pm 0.00$ & $22.20 \pm 2.70$ & $57.22 \pm 7.30$ & $17.63 \pm 1.00$ \\
Allium sativum (500 & $0.50 \pm 0.10(-4.83)$ & $20.73 \pm 2.91(-7.00)$ & $56.65 \pm 6.90(-0.99)$ & $17.34 \pm 1.09(-1.60)$ \\
mg/kg body weight) & & & & \\
\hline
\end{tabular}

Values are expressed as mean \pm SD of six rats, values in the parenthesis are percent change (changes are non significant). Units $\mathrm{a}=\mathrm{mg} / \mathrm{dl}, \mathrm{b}=$ units/l, $\mathrm{c}=$ units/dl 
DISCUSSION: In normal rats treatment with Allium sativum at the doses of $500 \mathrm{mg} / \mathrm{kg}$ body weight orally once in a day for 15 days did not alter significantly, their body weight Table 1 or blood biochemical parameters namely the levels of glucose, serum protein-lipid profile Table 2 , lipoprotein profile Table 3, a free fatty acid with lipolytic enzyme activities Table 4, lipid peroxide and antioxidant enzymes Table 5. Also, there was no significant change in the hepatospecific parameters like serum bilirubin (S. bil), serum glutamate pyruvate transaminase (SGPT), serum glutamate oxaloacetate transaminase (SGOT) and alkaline phosphatase (ALP) Table 6. This indicated that the herbal preparations, as such, did not exert any adverse and toxic side effects during treatment in rats. The results of the present study demonstrated that natural products did not cause a significant decrease in biochemical parameters in healthy normal rats ${ }^{32-34}$. That's why it very clear here if a healthy person will take natural products, it never causes hypoglycemia, hypolipidemia and under the weight. Natural products also not cause any significant change in hepatospecific parameters. Thus from this study, we conclude that natural products are safe, non-toxic, and free from side effects in comparison to synthetic drugs ${ }^{35-38}$.

CONCLUSION: It should be pointed out here that plant-derived natural compounds have established a proven platform for developing new drug synthesis with fewer side effects or free from side effects.

Ethical Approval: This article does not contain any studies with human participants performed by any of the authors. The study was approved by the Institutional Animal Ethics Committee of Central Drug Research Institute and was carried out in accordance with the current guidelines set by Organization for Economic Co-operation and Development (OECD), received from Committee for the Purpose of Control and Supervision of Experiments on Animals (CPCSEA), Ministry of Social Justice and Empowerment, Government of India for the Care of Laboratory Animals:

ACKNOWLEDGEMENT: One of us (Dr. Vishnu Kumar) is grateful to the Director, Central Drug Research Institute (CDRI), Lucknow for experimental support, Director Academics, Era's Lucknow Medical College and Hospital, Lucknow for financial support, Principal, Autonomous State Medical College, Shahjahanpur for moral support as well as guidance and Late Dr. Ramesh Chander retired Scientist, Biochemistry, Division, CDRI, Lucknow for his expert guidance for the period of this research.

CONFLICTS OF INTEREST: The authors declare that they have no conflicts of interest.

\section{REFERENCES:}

1. Zhai B, Zhang C, Sheng Y, Zhao C, He X, Xu W, Huang $\mathrm{K}$ and Luo $\mathrm{Y}$ : Hypoglycemic and hypolipidemic effect of S-allyl-cysteine sulfoxide (alliin) in DIO mice. Scie NTIFIC Reports 2018; 8: 3527.

2. Banerjee SK and Maulik SK: Effect of garlic on cardiovascular disorders: a review. Nutr J 2002; 1(1): 1-4.

3. Bakhshi R and Chughtal MI: Influence of garlic on serum cholesterol, serum triglycerides, serum total lipids and serum glucose in human subject. Nahrung 1984; 28(2): 159-63.

4. Lau BHS, Lam F and Wang-Cheng R: Effect of an odor modified garlic preparation on blood lipid. Nut Res 1987; 7: 139-49.

5. Qureshi AA, Din ZZ and Abuirmeileh N: Suppression of avain hepatic lipid metabolism by solvent extract of garlic: impact on serum lipid. J Nut 1983; 113: 1746-55.

6. Bordia A: Effect of garlic on blood lipids in patients with coronary heart disease. Am J Clin Nutr 1981; 34: 2100-3.

7. Jain RC: Onion and garlic in experimental induced atherosclerosis. Ind J Med Res 1976; 76: 1508-15.

8. Ziaei S, Hantoshzudeh S, Rexasoltani P and Lamyian: The effect of garlic tablets on plasma lipids and platelets in nulliparous pregnant at high risk of pre-eclampsia. Eur $\mathbf{J}$ Obstet Gynecol Reprod Bio 2001; 99: 201-6.

9. Superko HR and Krauss RM: Cholesterol reduction in cardiovascular disease: clinical benefits and possible mechanism. New Engl J Med 2000; 322: 512-21.

10. Berthold HK, Sudhop T and Bergmann VK: Effect of a garlic oil preparation on serum lipoproteins and cholesterol metabolism: a randomized control trial. JAMA 1998; 279: 1900-2.

11. Verma RK, Goswami S, Singh AP, Tripathi P, Ojha G and Rai M: A review on hypoglycemic, hypolipidemic and anti-obesity effect of Allium sativum. J Chemi and Pharmaceu Sci 2014; 7(8): 321-29.

12. Gupta R, Joshi P, Mohan V, Reddy KS and Yusuf S: Epidemiology and causation of coronary heart disease and stroke in India. Heart 2008; 94: 16-26.

13. Mohammed K, Ali KM, Narayan $\mathrm{V}$ and Tandon $\mathrm{N}$ : Diabetes and coronary heart disease: Current perspectives. Indian J Med Res 2010; 130: 584-97.

14. Chattopadhyaya R, Pathak D and Jindal DP: Antihyperlipidemic agents. a review. Indian Drugs 1996; 33: 85-97.

15. Satyavati GV and Guggulipid: A promising hypolipedemic agent from gum guggul (Commiphora wightii). in economic and medicinal plant research, plants and traditional medicine. Acad Pres New York 1991; 5: 47-82.

16. Kumar V, Mahdi F, Khanna AK, Singh R, Chander R, Saxena JK, Mahdi AA and Singh RK: Antidyslipidemic and antioxidant activities of Hibiscus rosa-sinensis root 
extract in alloxan induced diabetic rats. Indian Journal of Clinical Biochemistry 2013; 28(1): 46-50.

17. Trinder P: Determination of glucose in blood using glucose oxidase with an alternative oxygen acceptor. Ann Clin Biochem 1969; 6: 24-30.

18. Mc-Cord JM and Fridovich IJ: Superoxide dismutase; an enzymic function for erythrocuprein (Hemocuprein). J Biol Chemistry 1969; 244: 6049-55.

19. Aebi H: Catalase in-vitro. Methods Enzymol 1984; 105 : 121-22.

20. Mosinger F: Photometric adaptation of dole's micro determination of free fatty acids. J Lipid Res 1965; 6: 15759

21. Reitman S and Frankel S: A colorimetric method for determination of serum glutamate oxaloacetate and glutamic pyruvate transaminase. Am J Clin Parhol 1957; 28: 56-58.

22. Deeg R and Ziegenborn J: Kinetic enzymatic method for automated determination of total cholesterol in serum. Clin Chem 1983; 29: 1798-03.

23. Buccolo $G$ and David H: Quantative determination of serum triglycerides by the use of enzymes. Clin Chem 1973; 19: 476-80.

24. Williams P, David R and Alan B: High density lipoprotein and coronary risk factor in normal men. The Lancet 1979; 313(8107): 72-75.

25. Nigam PK. Calculated low density lipoprotein cholesterol: Friedwald's formula versus other modified formulas. Int $\mathrm{J}$ Lif Sci and Med Res. 2014; 4(2): 25-31.

26. Nagasaki $T$ and Akanuma $Y$ : A new calorimetric method for the determination of plasma lecithin: cholesterol acyltransferase activity. Clin Chem Acta 1977; 75: 371-75.

27. Ohkawa $\mathrm{H}$ and Ohishi N: Reaction of thiobarbituric acid with linoleic acid hydroperoxide. J Lipid Res 1978; 19: 1053-57.

28. Ellman G: Tissue sulfhydryl groups. Arch Biochem 1959; 82: 70-77.

29. Burstein $M$ and Legmann P: Monographs on atherosclerosis. In Lipoprotein Precipitation Ed by $\mathrm{T}$ B Clarkson S Kargar London 1982; 2: 76-83.

30. Deeg R and Ziegenborn J: Kinetic enzymatic method for automated determination of total cholesterol in serum. Clin Chem 1983; 29: 1798-03.

31. Radding, CM and Steinberg D: Studies on the synthesis and secretion of serum lipoproteins by rat liver slices. $\mathbf{J}$ Clin Invest 1960; 39: 1560-69.

32. Woodson RF: Statistical methods for the analysis of biochemical data. Chichester Wiley 1957: 315.

33. Linthout SV, Spillmann F, Schultheiss HP and Tschöpe C: High-Density lipoprotein at the interface of type 2 diabetes mellitus and cardiovascular disorders. Curr Phar Desi 2010; 16: 1504-16.

34. Hedrick CC, Thorpe SR, Fu MX, Harper CM, Yoo J, Kim SM, Wong $\mathrm{H}$ and Peters AL: Glycation impairs highdensity lipoprotein function. Diabetologi 2000; 43: 312-20.

35. Kumar V, Mahdi F, Chander R, Husain I, Khanna AK, Singh R, Saxena JK, Mahdi AA and Singh RK: Tinospora cordifolia regulates lipid metabolism in allaxon induced diabetes in rats. Int J Pha and Lif Sc 2013; 4(10): 3010-17.

36. Block E: The chemistry of garlic and onion. Sci Am 1985; 252: 114-9.

37. Chetty KN, Calahan L and Harris KC: Garlic attenuates hypercholesterolemic risk factors in olive oil fed rats and high cholesterol fed rats. Pathophysiol 2003; 9(3): 127-32.

38. Bordia A and Verma SK: Effect of garlic feeding on regression of experimental atherosclerosis in rabbits. Artery 1980; 7(5): 428-37.
39. Banerjee SK and Maulik SK: Effect of garlic on cardiovascular disorders: a review. Nutr J 2002; 1(1): 4.

40. Kumar V, Mahdi F, Singh R, Mahdi AA and Singh RK: A clinical trial to assess the antidiabetic, antidyslipidemic and antioxidant activities of Tinospora cordifolia in management of type- 2 diabetes mellitus. Int J Pharm Sci Res 2016; 7(2): 757-64.

41. Singh M, Anwer E and Kumar V: Assessment of biochemical parameters in the patients of coronary artery disease with type 2 diabetes mellitus. Int J Pharm Sci Res 2017; 8(3): 1420-26.

42. Singh C, Kawatra R, Gupta J, Awasthi V and Dungana H: Therapeutic role of vitamin B12 in patients of chronic tinnitus: a pilot study. Noise Health (Serial Online) 2016; 18: 93-7.

43. Rathore B, Singh M, Kumar V and Misra A: Osteocalcin: an emerging biomarker for bone turnover. Int J Res Med Sci 2016; 4: 3670-4.

44. Neerja J, Verma P, Kumar V, Mahdi F, Mahdi AA, Khanna AK, Saxena JK and Singh RK: Antidyslipidemic and antioxidant activity of medicinal plants in rat model of hyperlipidemia. Int J Pharm Sci Res 2016; 7(11): 4579-87.

45. Verma P, Rathore B, Kumar V, Mahdi AA and Singh RK: Allium sativum regulates lipid metabolism in alloxan induced diabetic rats. Int J Pharm Sci Res 2016; 7(12): 4949-55.

46. Kumar V, Mahdi F, Singh R, Mahdi AA and Singh RK: A clinical trial to assess the antidiabetic, antidyslipidemic and antioxidant activities of Tinospora cordifolia in management of type- 2 diabetes mellitus. Int $\mathrm{J}$ Pharm Sci Res 2016; 7(2): 757-64.

47. Kumar V, Salam A, Misra A, Jafri RT, Anwer E and Singh $S$ : The prevelence of obesity and overweight amongst students and staff of era's Lucknow Medical College \& Hospital Lucknow. EJMR 2018; 5(1): 9-16.

48. Singh S, Kumar V, Singh K, Karoli R and Mahdi F: Status of TNF- $\alpha$ and insulin in obese and diabetic obese subjects of western Lucknow. EJMR 2018; 5(1): 17-21.

49. Kumar V and Abdussalam: A review on antioxidants and oxidative stress in type-2 diabetes mellitus. EJMR 2017; 4(2): 47-51.

50. Kumar V, Mahdi F, Saxena JK, Singh RK, Srivastava MR and Ahmad S: Effects of natural products on body weight and biochemical parameters in healthy rats. EJMR 2017; 4(2): 30-37.

51. Kumar V, Mahdi F, Saxena JK, Singh RK, Akhter N and Ahmad S: Experimental validation of antidiabetic and antioxidant potential of $T$. cordifolia stems (M.): an indigenous medicinal plant. EJMR 2017; 4(2): 10-15.

52. Kumar $\mathrm{V}$ and Abdussalam: A review on reactive oxygen and nitrogen species. EJMR 2017; 4(2): 40-45.

53. Kumar V: A review on etiopathogenesis of type- 2 diabetes mellitus. EJMR 2017; 4(1): 49-53.

54. Vishnu Kumar, Medicinal properties of Anthocephalus indicus (Kadam): an indigenous medicinal plant. EJMR 2017; 4 (1): 63-67.

55. Kumar V: Text book of biochemistry for medical students by: DM Vasudevan and Kannam Vidyanathan. EJMR 2017; 4(2): 57.

56. Kumar V, Singh R and Singh RK: Review on role of herbal remedies on cardiovascular system, a book chapter, book of biomedical sciences and herbal medicines, published by discovery publishing house, Pvt. Ltd. New Delhi India 2017: 329-40.

57. Kumar V, Singh R, Mahdi F, Mahdi AA and Singh RK: Experimental validation of antidiabetic and antioxidant potential of Cassia tora (L.): an indigenous medicinal 
plant. Indian Journal of Clinical Biochemistry 2016; doi: 10.1007/s12291-016-0608-3.

58. Singh M, Choudhury I, Pallinti V, Jothimalar R, Kumar V and Misra A: Association between pro 12 ala polymorphism at the Ppar $\Upsilon 2$ gene and insulin sensitivity in south Indian population with type 2 diabetes mellitus. Ind Journal Basic and App Med Res 2016; 5(3): 733-41.

59. Kumar V: Antidyslipidemic and antioxidant activities of Tinospora cordifolia stem extract in alloxan-induced diabetic rats. Ind J of Clin Biochem 2015; 30(4); 473-78.

How to cite this article:

Bhatt S, Malik K and Kumar V: Effects of Allium sativum on body weight and biochemical parameters in healthy rats. Int J Pharm Sci \& Res 2020; 11(9): 4442-48. doi: 10.13040/IJPSR.0975-8232.11(9).4442-48.

All @ 2013 are reserved by the International Journal of Pharmaceutical Sciences and Research. This Journal licensed under a Creative Commons Attribution-NonCommercial-ShareAlike 3.0 Unported License.

This article can be downloaded to Android OS based mobile. Scan QR Code using Code/Bar Scanner from your mobile. (Scanners are available on Google Playstore) 